\title{
PENGGUNAAN INSTAGRAM \\ SEBAGAI TREND MEDIA DAKWAH MASA KINI \\ STUDI AKUN INSTAGRAM PONDOK PESANTREN NURUL JADID
}

\author{
Zakiyah Romadlany, Farhan \\ Universitas Nurul Jadid Paiton Probolinggo \\ romadlanyzakiyah31@gmail.com,farhan.alim11@gmail.com
}

\begin{abstract}
This article explains about the use of Instagram as a contemporary media propaganda trend. The rise of social media made the preachers intrigued to channel their da'wah using Internet networks. Media is a tool for channeling communication to other people. While da'wah is inviting others to goodness. If it is concluded, the da'wah media is a tool to invite others to a better way. Media Instagram is a very interesting media to be used as a media for propaganda. Remembering da'wah can use images and audio visuals. This research is a case study of the mahasantri response to da'wah messages contained in the Instagram account of Pondok Pesantren Nurul Jadid (PPNJ). Qualitative descriptive method becomes a method to help researchers analyze the collected data. Based on collected data. Showing good response and the message posted is used as a reference or motivation to be better.
\end{abstract}

Keywords: instagram, da'wah media, da'wah message, response.

Abstrak: Tulisan ini menjelaskan tentang penggunaan instagram sebagai trend media dakwah masa kini. Maraknya media sosial membuat para pendakwah tergelitik untuk menyalurkan dakwahnya menggunakan jejaring Internet. Melihat media adalah alat untuk menyalurkan komunikasi kepada orang lain. Sedangkan dakwah adalah mengajak orang lain menuju kebaikan. Jika disimpulkan media dakwah yaitu alat untuk mengajak orang lain ke jalan yang lebih baik. Media Instagram adalah media yang sangat menarik untuk dijadikan media dakwah. Mengingat dakwah bisa menggunakan gambar dan audio visual. Penelitian ini merupakan studi kasus tentang respon mahasantri terhadap pesan dakwah yang terkandung dalam akun Instagram Pondok Pesantren Nurul jadid (PPNJ). Metode deskriptif kualitatif menjadi metode untuk membantu peneliti untuk menganalisa data yang terkumpul. Berdasarkan data yang terkumpul. Menunjukkan respon baik dan pesan yang di posting banyak dijadikannya sebagai acuan atau motivasi untuk menjadi lebih baik.

Kata kunci: instagram, media dakwah, pesan dakwah, respon. 


\section{Prolog}

Kehadiran media sosial sangatlah berpengaruh terhadap pola kehidupan manusia, lebih-lebih dalam hal perilaku. Dengan adanya media sosial, manusia sangat terbantu dalam kegiatan sehari-harinya. kegiatan penyampaian pesan berlansung lebih cepat, mudah, dan efektif, bahkan lebih up to date. Terlebih munculnya aplikasi media sosial; Facebook, WhatshApp, Twitter, Instagram, dan lainnya. Pesan dalam bentuk visual, audio, audio-visual semakin menumpuk dan saling berkompetisi antara satu pengguna dengan pengguna lainnya. Teori uses and gratification masih dalam perdebatan akademik, antara relevan dan sudah tidak lagi relevan bagi masyarakat melek teknologi saat ini. Kendatipun, hasil penelitian penggunaan media dalam komunitas pendengar radio Grass FM, radiao dalam operasionalisasinya berbasis internet ini, masih memiliki relevansi yang kuat dalam bentuk aktifitas pengguna media secara interaktif. ${ }^{1}$

Kendati demikian, pemilihan dan intensitas penggunaan media memiliki perbedaan sesuai kategori sosialnya. Seperti latar belakang jenis kelamin, pendidikan, pekerjaan, agama dan pendapatan. ${ }^{2}$ Ruang-ruuang yang tersedia dalam interaksi media sosial bagi penggunanya, merupakan ruang bebas yang memicu para penyampai-penerima pesan dan pengikut (Followers) selalu menunjukkan eksistensi diri dan komunitas. Bahkan melalui media sosial Istagram mampu menjadikan seorang individu layaknya artis dengan penggemar meningkat. Seperti, akun istagram Ayasha Putri, seorang balita yang oleh orang tuanya yang mengunggah foto dan video (postingan) sebanyak 864, memiliki 475 ribu pengikut (followers). ${ }^{3} \mathrm{Jadi}$, siapapun dan komunitas apapun bisa berkompetisi dalam memiliki jumlah followers yang terus meningkat, baik menguggah pesan (informasi) positif maupun negatif.

Ironisnya, media sosial masih digunakan untuk menyampaikan pesan-pesan yang negatif. Catatan kominfo sepanjang Januari hingga November tahun 2018, menyebutkan media sosial facebook dan istagram paling banyak berisi konten negatif dengan jumlah 8.903 pelaporan masyarakat. Dibandingkan Twitter berjumlah 4.985 laporan dan google

\footnotetext{
${ }^{1}$ Parulian Sitompul, "Penggunaan Media Oleh Komunitas", Komunikasi dan Media, Vol. 18. No. 1 (Januari-juni, 2014), 21-23 dalam https://jurnal.kominfo.go.id/index.php/jskm/article/view/180102

${ }^{2}$ Rukman Pala, Penggunaan Internet dan Kategori Sosial Penggunanya, Komunikasi dan Media, Vol. 18. No. 1 Januari-Juni 2014.1-19 dalam https://jurnal.kominfo.go.id/index.php/jskm/article/view/180101/159

${ }^{3}$ Nadia Faidatun Nasiha, Pengaruh Penggunaan Media Sosial Istagram terhadap Cintra Tubuh Mahasiswa Fakultas ushuluddin Adab dan Dakwah IAIN Ponorogo tahun 2016, Dialogia, Vol. 15, No. 2, Desember 2017, h. 340
} 
serta Youtube sebanyak 1.683 laporan. ${ }^{4}$ Bahkan pertumbuhan pengguna aplikasi istagram disebutkan mengalahkan facebook dan Snapchat, Istagram tembus pada angka 1 miliar per Juni $2018 .^{5}$

Media sosial aplikasi Instagram yang masih berumur sekitar lima tahun, sudah memiliki pengguna sudah mencapai 400 juta pengguna aktif. Pencapaian angka ini adalah sebuah prestasi bagi Instagram. Karena sebelumnya pada tahun 2014 pencapaiannya hanya berkisar 300 juta orang. ${ }^{6}$.

Pengguna Instagram ini bermacam-macam, dan kebanyakan para penggunanya menggunakan passion yang mereka sukai. Seperti halnya para pendakwah, mereka bisa menggunakan akun Instagram ini sebagai lahan untuk berdakwah. Para pendakwah tidak hanya bisa menyampaikan dakwahnya dengan bil-kalam atau bil-kitabah saja, tetapi para pendakwah bisa menyampaikannya dengan menggunakan gambar, ataupun visual yang mereka sukai melalui akunnya. Karena akun yang seperti ini merupakan akun yang trend pada saat ini. Lebih-lebih untuk menyebar luaskan dakwah dengan menggunakan gambar ataupun visual yang menarik untuk dilihat, dibaca serta diperhatikan.

Maka pada dasarnya bagi para pendakwah tidak hanya bisa menuangkan pemikirannya hanya di sebuah forum seperti di masjid, sekolah, kampus dan tempat-tempat lain yang hanya di hadiri oleh sekelompok orang. Akan tetapi, jika menggunakan jejaring sosial seperti Instagram, semua khalayak yang memiliki akun juga bisa melihat dan membacanya. Dan tidak perlu repot-repot menghadiri sebuah forum. Yang kadang kala berbentrokan dengan pekerjaannya. Jadi dengan aplikasi Instagram ini sangatlah mempermudah bagi seseorang yang ingin menuangkan pemikirannya, tidak hanya bagi para pendakwah yang bisa menuangkan pemikirannya. Kita pun juga bisa menuangkan pemikiran kita dengan menggunakan aplikasi tersebut. Lebih-lebih untuk mengajak seseorang kepada kebaikan. Bisa dikatakan bahwa akun Instagram ini memiliki nilai dakwah secara mudah dan efektif. Dilihat dari penelitiannya memiliki unsur pesan dakwah dan keunggulan visualnya menarik kemasan yang di sampaikan kepada semua orang, terdapat gambar serta bahasa yang mudah di pahami.

\footnotetext{
4 https://www.kominfo.go.id/content/detail/15739/tahun-2018-facebook dan instagram -jadi-media-sosial-paling-banyak-konten-negatif/0/berita_satker ${ }^{5}$ Fatimah Kartini Bohang, Juni 2018, Pengguna aktif Istagram Tembus 1 Miliar, https://tekno.kompas.com/read/2018/06/21/10280037/juni-2018-pengguna-aktifinstagram-tembus-1-miliar,

${ }^{6}$ Nur Rizky Toybah, "Dakwah Komunikasi Visual Melalui Instagram Akun@ Haditsku”,https://www.researchgate.net/publication/317429523_Dakwah_Komunik asi_Visual_Melalui_Instagram_Akun_HADITSKU, Alhiwar Jurnal Ilmu dan teknik Dakwah, Vol. 04 No. 07, Januari-Juni, 2016,58-59.
} 
Melihat begitu padatnya pemanfaatan internet dan jejaring sosial, maka, penyebaran kebaikan (berdakwah) sangatlah efektif jika internet sebagai sarana atau medianya ${ }^{7}$ dengan adanya media jejaring sosial ini sangat banyak menguntungkan khalayak. Karena dengan jejaring sosial, khalayak bisa dengan mudah mendapatkan nasihat-nasihat harian selain pendakwah atau para ustadz tanpa jejaring. ${ }^{8}$ Maka, dengan begitu para pendakwah dan ustadz akan sangat mudah untuk menyalurkan dakwah atau pemikirannya. Melihat jejaring sosial sudah menjadi aplikasi yang sangat di minati oleh khalayak.

Media sosial menjadi salah satu media yang sangat membantu untuk para pendakwah, khususnya para pendakwah multimedia, seperti halnya, facebook, Instagram, whatsapp, youtube dan sebagainya. Hal ini di sebabkan dengan semakin maraknya pengguna media dikalangan masyarakat. ${ }^{9}$ Para pendakwah, khususnya pendakwah multimedia lebih memilih jejaring sosial sebagai ajang untuk berdakwah. Dengan adanya jejaring sosial ini, para pendakwah selain menyampaikan pesannya di tempat-tempat tertentu, para pendakwah juga bisa menyampaikannya di jejaring sosial seperti Facebook, Instagram, Blog dan berbagai akun lainnya.

Dengan adanya aplikasi media sosial, dapat mempermudah bagi para pendakwah untuk membagikan sebuah pemikirannya kepada khalayak dengan menggunakan sebuah gambar ataupun video-vide berdurasi untuk direnungkan dan dicerna maknanya. Sehingga kebanyakan dari para pembaca/penonton bisa merenungkan apa yang mereka lihat dan mereka baca dalam aneka macam pesan media berjejaring. Semakin hari, pengguna media akan semakin meningkat dan pesan-pesan yang disampaikan semakin mendapatkan perhatian penggunanya.

Umat Islam, sebagai pendakwah baik secara individu maupun komunitas, harus mempergunakan media-media komunikasi baru sebagai media dakwah. Pesantren Nurul Jadid Paiton Probolinggo ${ }^{10}$ sebagai salah satu organisasi dakwah di Nusantara, ikut andil dalam rangka eksistensi dan dinamisasi dakwah Islam zaman kekinian. Melalui beragam kebijakan-

\footnotetext{
${ }^{7}$ Eko Sumadi, “Dakwah dan Media Sosial: Menebar Kebaikan Tanpa Diskrimasi”, Komunikasi Penyiaran Islam, 01 (Juni 2016), 173-190.

${ }^{8}$ Ahmad Fathan Hidayatullah, "Twitter Sebagai Media Dakwah", Teknoin,01 (Maret, 2016), 38-43.

9 Farhan, 'PESAN DAKWAH FELIX SIAUW DI MEDIA SOSIAL', Jurnal Manajemen Dan Administrasi Islam, 1.2 (2017), 209-26.

${ }^{10}$ Pesantren yang berada di Tapal Kuda Jawa Timur ini berdiri sekitar tiga tahun pasca kemerdekaan. Didirikan oleh KH. Zaini Mu'im (Kyai Kharismatik keturunan Madura), pada masa penjajahan sebagai pemimpin Laskar Sabilillah di Madura, sehingga memilih Hijrah ke luar Madura. Sekaligus melakukan dakwah Islam kepada masyarakat Luas. Lebih lengkap lihat https://www.nuruljadid.net/sejarahpesantren.
} 
kebijakan pesantren dalam semua aspek. Setidaknya, sebagai lembaga dakwah, pesantren selalui memberikan pesan dakwah 'amar ma'ruf nahi munkar' kepada para santri, alumni serta masyarakat sekitar. salah satunya adalah pemanfaatan teknologi modern dengan aplikasi media sosial istagram sebagai tren media dakwah.

Berdasarkan gambaran tersebut penulis tertarik untuk melakukan penelitian. fokus masalah yang dipilih adalah pesan dakwah dan respon pengguna akun Instagram dikalangan mahasiswa santri Univesitas Nurul Jadid (sebagai mad'u) dalam merespon pesan dakwah dalam akun tersebut.

\section{METODE PENELITIAN}

Penelitian ini merupakan metode penelitian deskriptif kualitatif dengan pengumpulan data secara triangulasi. Objek penelitian adalah akun Instagram Pondok Pesantren Nurul Jadid dalam akun PPNurulJadid. Data dikumpulkan dari dokumentasi online dan juga melalui triangulasi data.

Para pendakwah yang menggunakan aplikasi Instagram tidak hanya mengaplikasikan tulisannya, melainkan juga bisa mengaplikasikannya dengan menggunakan gambar atau audio visual yang akan sedikit lebih menarik pembaca dan para pengguna aplikasi Instagram lainnya. Dan dengan begitu para pendakwah bisa mengaplikasikan dakwah multi medianya sebagai wadah untuk berdakwahnya. Para pendakwah hanya cukup duduk dengan menyalurkan imajinasinya untuk mengotak atik materi yang akan disampaikannya dengan berbagai macam keterampilan tangannya, misalnya dengan suatu gambar yang di padukan dengan kata-katanya yang cukup menarik untuk para pembaca atau bisa juga dengan karya kaligrafinya yang cukup memberikan sebuah makna yang tersirat didalamnya. Seperti halnya kaligrafi hidup yang dirangkai dengan beberapa ayat dengan lukisan pasir dan disertai dengan pernak-pernik warna yang cukup menarik dan memiliki arti yang sangat sakral. Sehingga memiliki daya tarik yang cukup menarik bagi para penggemar kaligrafi.

\section{Media Dakwah}

Media bersal dari bahasa latin yaitu "medius" yang berarti perantara. Sedangkan dalam bahasa Inggris yaitu "medium" yang memiliki arti tengah atau rata-rata. Ahli komunikasi memberikan pengertian bahwa media adalah alat yang menghubungkan pesan dari komunikasi yang disampaikan oleh komunikator untuk komunikan. ${ }^{11}$ sedangkan dakwah dapat diartikan sebagai mengajak, ${ }^{12}$ yaitu mengajak suatu pekerjaan atau tingkah laku untuk menuju kebaikan. Dan meninggalkan perbuatan yang

\footnotetext{
${ }^{11}$ Moh. Ali Aziz, Ilmu Dakwah, Prenada media group, (Jakarta :2015), 403.

${ }^{12}$ Munzier Suparta, Metode Dakwah (Jakarta: Kencana,2006).61
} 
terlarang. dakwah memiliki kaitan dengan suatu usaha, baik menggunakan lisan ataupun tulisan yang bersifat mengajak manusia untuk beriman dan mentaati segala perintah Allah. ${ }^{13}$

Dalam buku Ilmu dakwah Ali Aziz mengungkapkan bahwa Dakwah merupakan denyut nadi Islam. Karena dengan adanya dakwah, Islam dapat bergerak dan hidup. ${ }^{14}$ Seiring berkembangnya zaman, semakin marak pula alat elektronik yang tersambung dengan internet. Maka semakin beragam tuntutan bagi dakwah untuk tidak lagi dilakukan dengan cara tradisional, seperti halnya berpindah dari suatu mimbar ke mimbar yang lain. Maka dengan begitu dakwah di kemas dengan metode dan media yang cukup tepat dan pas. ${ }^{15}$

Dakwah berkaitan dengan seorang pendakwah. Pendakwah ini adalah seseorang yang memaparkan atau mengaplikasikan pesan dakwahnya kepada mad'u atau pendengarnya. Agar pesan-peasn para pendakwah bisa tersalurkan, para pendakwah juga membutuhkan media dakwah (washilah) untuk dijadikan perantara penyampaian pesan dakwahnya. Maka dengan adanya media sosial seorang pendakwah sangatlah memiliki ruang untuk memperluas penyampaian pesannya. Tanpa harus mengahadiri sebuah pengajian atau temapat-tempat tertentu seperti masjid dan sekolah. Maka dengan adanya media sosial para pendakwah sangatlah terbantu untuk mejadikannya sebagai media untuk berdakwah. Mengutip dari Hamzah Ya'qub beliau membagi media dakwah dalam lima kategori, antaranya lisan, tulisan, lukisan, audio visual serta akhlak. ${ }^{16}$

Abdur Kadir Munsyi juga memaparkan enam jenis media dakwah antaranya : lisan, tulisan, lukisan / gambar, audio visual, perbuatan serta organisasi. ${ }^{17}$ Sedangkan dalam ilmu komunikasi, media diklafikasikan dalam tiga macam yaitu : pertama, media terucap (the spoken words) adalah alat yang bisa mengeluarkan suara atau bunyi. Seperti telepon, radio dan sebagainya. Kedua media tertulis ( the printed writing) adalah media yang berupa tulisan atau cetak. Seperti surat kabar, buku, majalah, pamflet, gambar, lukisan dan sebagainya. Ketiga, media dengar pandang (the audio visual) adalah media yang isinya berupa gambar hidup dan bisa dilihat serta didengar. Seperti televisi, film, vidio dan sebagainya. ${ }^{18}$

\footnotetext{
${ }^{13}$ Aziz, Ilmu Dakwah, 05

${ }^{14}$ Ibid., 05

${ }^{15}$ M Ali Musyafak, "Film Religi Sebagai Media Dakwah", Islamic Review,02 (Oktober 2013), 327-338.

${ }^{16}$ A Zaini, "Dakwah Melalui Internet", Komunikasi Penyiaran Islam, 1.1 (2013), 93-108.

${ }^{17}$ moh. Ali Aziz, Ilmu Dakwah, 2015.

${ }^{18}$ Aziz, Ilmu Dakwah.406
} 
Menurut Rully Nasrullah mengutip dari Manovich mengatakan bahwa perangkat komputer (interfaces) bukan hanya sebagai medium yang menghubungkan antara manusia atau mesin dalam jaringan informasi diinternet, tetapi sudah menjadi budaya yang mengatur manusia untuk melakukan koneksi dengan jaringan informasi dan berhubungan dengan data di internet. ${ }^{19}$

Sebagaimana dikutip Farhan dari Andi Faishal bahwa dengan berkembangnya media, harus dijadikan sebagai media atau objek dakwah dengan melakukan "islamisasi media". Maka konsep dakwah akan setara dengan konsep komunikasi. Karena menurutnya dakwah dengan menggunakan Internet memiliki nilai efektif dan berkemampuan untuk menyebarkan tata nilai, etika dan moral luhur yang mulia. ${ }^{20}$

Guru ngaji adalah potret seorang pendakwah. Karena guru nagji juga memaparkan beberapa metode dakwah dan bersifat terus menerus. Guru ngaji ini bisa dikatakan sebagai media dakwah, baik guru ngaji langgaran ataupun pesantren. Objeknya pun di kategorikan dalam dua bagian antaranya: objek yang tertutup yaitu sasaran dakwahnya bisa dikatakan tetap. sedangkan kategori terbuka yaitu sasaran dakwahnya bisa berubah-rubah. Melihat dari kewajiban berdakwah, dengan mempertimbangkan situasi, kondisi serta tuntutan keadaan. Berdakwah adalah suatu hal yang wajib atau fardlu untuk dilakukan. Maka pendakwah diartikan sebagai muslim yang setiap geraknya dan dimanapun tempatnya senantiasa tetap menyalurkan kebaikan, menyampaikan nilai-nilai ajaran agama islam. Maka dapat disimpulkan bahwa guru ngaji termasuk pendakwah dan mengajarkan ngaji termasuk sebagai media untuk berdakwahnya.

Syafaar Habib mengungkapkan bahwa surat kabar juga termasuk sebagai media dakwah. karena melihat dari fungsi surat kabar yaitu membentuk opini, merubah sikap, dan mengarahkan tingkah laku seseorang baik individu maupun kelompok. Jika dikaitkan dengan al-Qur'an media dakwah akan menemukan contoh seperti pentingnya baca tulis sebagai media untuk berdakwah. Hal ini terdapat dalam surah Al-'Alaq ayat 1-5;

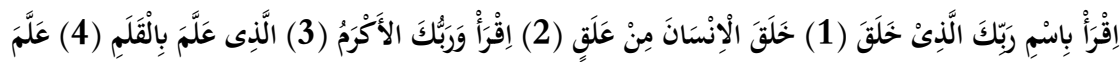

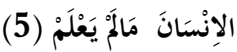

"Bacalah, dengan nama tuhanmu Dzat Yang mencipkatakan. (1) Dia telah menciptakan manusia dari segumpal darah. (2) Bacalah, dengan nama

\footnotetext{
${ }^{19}$ Aziz, Ilmu Dakwah.405

${ }^{20}$ Farhan, 'Religuitas Komunitas Muslim Di Media Sosial ( Studi Kasus Tilawah Al-Qur ' an Alumni Pramuka UIN Sunan Ampel Surabaya )', Asy-Syari'ah, 02 ( Juni 2018), 41-63.
} 
tuhanmulah Yang Maha Pemurah. (3) yang mengajar dengan perantaraan kalam. (4) Dia mengajar manusia sesuatu yang tidak diketahui.

Surat kabar mempunyai pengaruh yang sangat kuat kepada pembaca. Hal ini dapat disimpulkan dengan beberapa teori antaranya: pertama, teori peluru ajaib (magic bullet theory), yaitu di kategorikan khalayak sebagai sosok yang tidak berdaya dengan ditembaki oleh peluru surat kabar, bisa menggerakkan perilaku khalayak sesuai arah yang dikehendaki. Kedua,teori jarum suntik (hypodermic belt theory), yaitu diibaratkan dengan seorang pasien yang diberi serum melalui jarum kecil kedalam tubuhnya, maka dengan kehalusan dan ketajaman jarum suntik itu bisa membuat pasien tersebut tidak berdaya. dan terakhir, teory lilitan tali pinggang (transmission belt theory). Yaitu Pesan-pesan yang terkandung dapat menarik kesadaran melalui cara-cara yang sangat halus. ${ }^{21}$

Surat kabar juga bisa dikatakan sebagai media dakwah kategori cetak atau juga bisa di katakan sebagai media multimedia yang memanfaatkan kerajinan tangannya. Sama halnya dengan dakwah dengan lukisan. Misalnya, kaligrafi ayat-ayat al-Qur' an atau Hadist-hadist Nabi.

Jika dilihat dari dakwah yang diterapkan oleh KH.Zaini Mun'in yang memang dari sejak kecil beliau sudah menjadi seorang muballigh. Karena menurutnya menyampaikan agama (islam) suatu amanat dari agama itu sendiri dan fitrah kepada manusia untuk mengembangkannya dan mengabdikan dirinya untuk agama. ${ }^{22}$

Metode yang diterapkan KH. Zaini Mun'im adalah dakwah bilisanil hal dan dakwah bilisanil maqal. Dakwah bilisanil hal ini, beliau terapkan dengan media dakwahnya menggunakan "filsafat alam" yaitu bersama-sama masyarakat dalam meningkatkan kesejahteraan. Dan dengan memanfaatkan potensi tanah yang ada. Baru setelah perekonomian masyarakat membaik, beliau menggunakan metode dakwah bilisanil maqolnya.

Pementasan wayang juga bisa dijadikan sebagai media dakwah. Dalang sebagai seorang juru dakwahnya. Karena dalam pementasannya seorang dalang menyampaikan pesan-pesan agamis. Kenapa dikatakan pementasan wayang juga sebagai media dakwah?, karena pada masa Walisongo, Sunan Kali jaga, menggunakan media wayang sebagai kegiatan dakwahnya. Dan kegitan tersebut membuahkan hasil. ${ }^{23}$ Pementasan wayang

\footnotetext{
${ }^{21}$ ST.Nasriah, "Surat Kabar Sebagai Media Dakwah", Dakwah Tabligh, 13.1 (2012), 161-76.

${ }^{22}$ M Nasikh Ridwan, M. Masyhur Amin, KH Zaini Mun 'im (Pengabdian Dan Karya Tulis), 1996.

${ }^{23}$ Yogyasmara P Ardhi and others, "Studi Pada Wayang Kulit Dalang Ki Sudardi Di Desa Pringapus Semarang ", 2010.
} 
ini masih sering di aplikasikan di pulau Jawa dan Bali. Karena menurutnya wayang ini masih merupakan seni tradisional di Indonesia.

\section{Media Sosial Instagram}

Instagram berasal dari kata "insta"yang berasal dari kata "Instan", seperti halnya kamera polaroid yang di kenal sebagai "foto instan". Sedangkan kata "gram" berasal dari kata "telegram" yang bekerja untuk mengirimkan pesan kepada orang lain dengan cepat. ${ }^{24}$ Instagram adalah sebuah aplikasi yang masih merupakan bagian dari facebook. Karena pada tanggal 9 april 2012 Instagram resmi diambil alih facebook dengan nilai hampir \$1 miliar. Jadi teman kita di facebook bisa mengikuti akun Instagram kita.

Instagram ini merupakan aplikasi yang digunakan untuk membagikan foto atau vidio. ${ }^{25}$ Instagram merupakan suatu aplikasi media sosial yang digunakan sebagai alat untuk mengambil foto atau gambar, menerapkan filter digital (pemberian efek pada foto) serta membagikannya. ${ }^{26}$ Instagram memiliki sisi unik yaitu fitur memotong foto menjadi persegi, sehingga sama seperti hasil kamera kodak polaroid atau instamatic.

Seiring berjalannya waktu, semakin banyak pengguna Instagram yang di gunakan sebagai wadah untuk membagikan foto atau vidio, sehingga para pendakwah pun tertarik untuk membagikan pesan dakwahnya lewat aplikasi ini. Pendiri instagram adalah Kevin Systrom dan Mike Krieger mereka adalah pengusaha Internet dan pemogram komputer. Sebulan kemudian instagram mampu merangkul 1 juta pengguna, kemudian setahun setelah itu, instagram mencapai 10 juta lebih pengguna. Dan pada tahun 2012 instagram mampu menyaingi pengguna facebook. ${ }^{27}$

Sistem sosial yang terdapat dalam instagram yaitu dengan mengikuti akun pengguna lainnya, atau memiliki pengikut instagram. dengan begitu komuikasi dapat terjalin. Dengan memberi komentari serta memberikan tanda suka terhadap foto yang di unggah. ${ }^{28}$ Pengikut disini,

\footnotetext{
${ }^{24}$ Meutia Puspita Sari, "Fenomena Pengguna Media Sosial Instagram Sebagai Komunikasi Pembelajaran Agama Islam Oleh Mahasiswa Fisip Universitas Riau", JOM FISIP, 4.2 (2017), 1-13.

${ }^{25}$ M. Arifin Wicaksono, "Pengaruh Media Sosial Instagram @ wisatadakwahokura Terhadap Minat Berkunjung FOLLOWERS", JOM FISIP, 4.2 (2017), 1-13.

${ }^{26}$ Eureka Intan Innova, "Motif Dan Kepuasan Pengguna Instagram Di Komunitas Instameet Indonesia", E-Komunikasi, 4.1 (2016), 1-11.

27 'Penemu Instagram Dan Sejarah Singkat Terlengkap _ Media Informasi Digital'.

${ }^{28}$ Siti Juariah Irwandani, "Pengembangan Media Pembelajaran Berupa Komik Fisika Berbantuan Sosial Media Instagram Sebagai Alternatif Pembelajaran", Ilmiah Pendidikan Fisika Al-Biruni, 05.April (2016), 33-42.
} 
menjadi suatu unsur yang penting, sedangkan jumlah tanda suka dari pengikut juga sangat mempengaruhi.

Aplikasi Instagram ini juga termasuk aplikasi yang cukup digemari oleh masyarakat Indonesia. Karena termasuk karakteristik masyarakat Indonesia yang gemar akan keeksisan diri, dan lebih-lebih diketahui oleh orang lain.

Intagram ini juga termasuk media sosialisasi diri karena hanya menampilkan foto dan gambar yang terbatas, Sehingga tidak mengandung hater. ${ }^{29}$ Menurut perusahaan riset dan analisis dari Inggris, TNS, menyatakan bahwa negara Indonesia merupakan negara ke-3 sebagai pengguna Instagram. ${ }^{30}$ Pengguna aktif akun Instagram kebanyakan remaja atau anak muda yang keseringan meng-update informasi dan mengunggah foto ke media sosial dengan rata-rata usia 18-24 tahun menunjukkan bahwa kebanyakan pengguna Instagram dari kalangan remaja terdidik dan mahasiswa termasuk tergolong pengguna aktif Instagram. ${ }^{31}$

Instagram memiliki istilah tersendiri dalam mencari teman yaitu dengan istilah mengikuti dan pengikut atau bisa dikatakan dengan follow dan follower. Berhubungan dengan kegitan like dan komen, instagram juga bisa melakukan aktifitas berbagi pesan yang disebut dengan Direct Messege (DM) dan yang sekarang lagi marak adalah InstStory yaitu aktivitas membagikan vidio secara langsung atau live. ${ }^{32}$

\section{Respon Pengguna media}

Asal kata dari respon adalah response, artinya adalah jawaban, tanggapan atau balasan. Sedangkan dalam kamus besar bahasa indonesia adalah tanggapan, reaksi dan juga jawaban. Dalam kamus besar ilmu pengetahuan respon adalah reaksi psikologi-metabolik terhadap suatu rangsangan yang bersifat otomatis seperti reaksi emosional langsung, dan yang bersifat terkendali. ${ }^{33}$

Respon juga bisa di katakan sebagai Umpan balik yang di berikan oleh mad'u atau komunikan terhadap apa yang telah di paparkan oleh

\footnotetext{
${ }^{29}$ Aat Ruchiat Nugraha Ajeng Jayanti Satyadewi, Hanny Hafiar, "PEMILIHAN AKUN MEDIA SOSIAL INSTAGRAM OLEH HOLIDAY INN BANDUNG", Jurnal the Messenger, 9.2 (2017), 153-62.

${ }^{30}$ Sari. http://palembang.tribunnews.com/2017/04/02/indonesia-negaraterbesar-ketiga-pengguna-sosmed-instagram).

${ }^{31} \mathrm{http} / / / \mathrm{m}$. okozone.com/read/2016/-1/14/2017/1288332/pengguna-istagramdi-indonesia-terbanyak-mencapai-89persendiaksespada11/2/2017

32 'Pengertian Instagram Beserta Sejarah Dan Fungsinya (Lengkap)'.

${ }^{33}$ Save D. Dagun, Kamus Besar Ilmu Pengetahuan, (Jakarta: Lembaga Pengkajian dan Kebudayaan Nusantara, 1997), 964.
} 
komunikator atau pendakwah. ${ }^{34}$ Umpan balik (feedback) bagaimana responnya terhadap pesan dakwah, baik dengan upaya perubahan pada diri mad'u atau bisa dengan komentar yang di berikan mad'u terhadap pendakwah.

Respon yaitu umpan balik yang memiliki pengaruh terhadap penetuan baik buruknya suatu komunikasi. Respon juga bisa di artikan sebagai sikap atau prilaku yang ditunjukkan seseorang ketika dalam proses komunikasi. Onong uchjana Efendi mengatakan bahwa respon adalah proses perubahan prilaku seseorang yang tampak akan berubah hanya dengan tiga model yaitu (S-O-R) yaitu Stimulus, Organism, dan Respon. ${ }^{35}$

Proses perubahan bisa dikatakan sebagai respon dari mad'u terhadap apa yang dipaparkan oleh komunikan atau pendakwah. Ada tiga proses perubahan yang akan terjadi kepada mad'u antaranya aspek pengetahuan (knowledge), aspek sikap (attitude), dan aspek prilaku (behavioral). Sedangkan menurut Jalaluddin Rahmat tiga proses perubahan yang akan terjadi kepada mad'u meliputi efek kognitif yaitu perubahan terhadap apa yang diketahui, dipahami atau ditanggapi oleh khalayak. Efek ini berkaitan terhadap pengetahuan, keterampilan, kepercayaan dan informasi. Kemudian Efek Afektif yaitu akan timbul ketika ada perubahan pada apa yang dirasakan, disenangi, atau di benci oleh khalayak. Yang berhubungan dengan sikap, emosi dan nilai. Yang terakhir Efek Behavioral yaitu sesuatu yang kembali kepada prilaku nyata yang dapat di teliti, berupa pola-pola tindakan, kegiatan atau kebiasaan berperilaku. ${ }^{36} \mathrm{Jadi}$ bisa dikatakan bahwa respon, jawaban atau tanggapan yang disebabkan dengan adanya peristiwa yang mendahuluinya.

Menurut Moh. Ali Aziz mengutip dari Majdi Hilali dalam bukunya yang berjudul Kaifa Nughayyir Ma bi Anfusina (bagaimana kita merubah diri kita). Ada tiga tahapan yang di paparkannya. Antaranya : akal, yaitu keyakinan tentang suatu tindakan. Hati, yaitu suara atau bisikan yang menyenangkan. Dan hawa nafsu yang dibuktikan oleh keinginan anggota tubuh dalam tindakan nyata. ${ }^{37}$ Kesimpulan ini berdasarkan dari firman Allah SWT yang berbunyi:

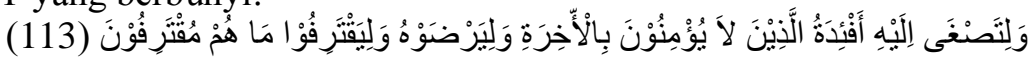
“..Dan (juga) agar hati kecil orang-orang yang tidak beriman kepada kehidupan akhirat cenderung kepada bisikan itu, mereka merasa senang kepadanya dan supaya mengerjakan apa yang mereka (setan) kerjakan. (QS. Al-An'aam(6):113).

\footnotetext{
${ }^{34}$ Moh.Ali Aziz, Ilmu Dakwah, Jakarta: Prenada Media Group, 2009, 196.

${ }^{35}$ Onong Uchjana Efendi, (2003:245).

${ }^{36}$ Ali Aziz, Ilmu Dakwah.

${ }^{37}$ Ibid,
} 


\section{Instagram; Tren Media dakwah Zaman Now}

Penggunaan akun Instagram ini tidak hanya dikalangan para pendakwah, melainkan juga dikalangan remaja milenial yang memiliki kesenangan untuk mengaplikasiannya hanya untuk mencari hiburan atau mencari motivasi untuk dirinya. Maka dengan begitu pesan dakwah dalam instagram sangatlah memiliki peluang besar sebagai wadah motivasi serta hiburan bagi remaja milenial.

Wahyu Ilahi dalam Nur Rizky mengatakan bahwa internet bisa menjadi salah satu alternatif untuk dakwah informasi dan globalisasi. Media dakwah memiliki peluang besar pada kesiapan pengembangnya dan pengembang media dakwahnya. ${ }^{38}$ Terutama bagi para calon-calon dakwah yang memiliki kekreativitasan dan keterampilan. Mereka bisa menggunakan dakwah multimedianya sebagai wadah untuk menyalurkan dakwahnya. Maka dengan begitu Instagram sangatlah berguna untuk dimanfaatkan sebagai media untuk berdakwah.

Karya tulis ilmiyah merupakan metode dakwah dalam bentuk keterampilan tangan sebagai penyampai pesan dakwah, keterampilan tangan tidak hanya berupa tulisan, melainkan gambar atau tulisan yang mengandung misi dakwah. ${ }^{39}$ Sedangkan instagram adalah media untuk menampilkan foto atau gambar. Maka, dengan begitu Instagram merupakan sebuah media yang sangat bermanfaat bagi para pendakwah melalui keterampilan tangannya baik dengan gambar atau visual.

Internet bisa dikatakan cukup praktis dan mudah jika dimanfaatkan sebagai media untuk berdakwah dibanding dengan harus berdakwah secara langsung. Bukan hanya karena jangkauannya yang luas, internet juga menghilangkan batasan rasisme, golongan, serta agama. Dengan internet seseorang bisa menyalurkan pemikirannya melalui tulisan atau audio visual tanpa adanya batasan waktu. ${ }^{40}$ Dimasa sekarang sudah ada beberapa pendakwah yang sudah menggunakan media instagram ini sebagai wadah untuk berdakwah.

Tidak hanya menggunakan gambar saja, Instagram juga bisa memposting video, akan tetapi video yang akan di post memiliki durasi yang tidak terlalu panjang, sehingga tidak akan menimbulkan kebosanan terhadap informan. Maka dengan begitu, bisa disimpulkan bahwa Instagram sangatlah efektif sebagai media untuk berdakwah.

Ahmad Zaini mengutip dari Moh. Ali Aziz mengatakan bahwa dengan menggunakan media sosial, dakwah akan bekerja dalam menyebarkan informasinya keseluruh dunia tanpa mengenal batas waktu

\footnotetext{
${ }^{38}$ Toybah, "Dakwah Komunikasi Visual.

${ }^{39}$ moh. Ali Aziz, Ilmu Dakwah, 2015.

${ }^{40}$ Busnatul Arifin, "Dakwah Cybermedia", Madzhab Hukum, 26.1 (2015), 201-19. 
dan tempat. ${ }^{41}$ Hal ini dilihat dari betapa meluasnya media sosial yang ada. Kendati demikian ada batasan yang harus diperhatikan dalam berdakwah di dunia maya. Pertama, meluruskan niat, yaitu di dasari dengan niat dan iktikad yang baik tidak bertujuan untuk memperdebatkan masalah madzhab. Kedua, merumuskan visi misi dakwah menggunakan media sosial yaitu memahami hakikat dakwah dengan memberikan manfaat kepada orang lain. Ketiga, menunjukkan nilai-nilai islam kepada dunia. Keempat, memilih pembimbing atau panutan yang ahli dalam urusan syariah dan memiliki wawasan yang luas. Kelima, konteks disesuaikan dengan kebutuhan dan kecenderungan masyarakat masa kini. Terakhir, situs yang dibuat dilengkapi dengan aplikasi-aplikasi unggulan, seperti chatting dan e-mail. ${ }^{42}$

\section{HASIL}

Sebagai media dakwah akun Instagram Pondok Pesantren Nurul Jadid (PPNuruljadid) cukup menarik perhatian para pengguna internet. Sejak Maret 2017 data yang diunggah oleh pengelola akun, menunjukkan jumlah pengikut IG (istagram) yang meningkat. Bagi para mahasiswa yang santri (mahasantri), media tersebut sangat tepat untuk diikuti dalam rangka mengikuti perkembangan pesantren.

Sampai saat ini pengikut Instagram Pondok Pesantren Nurul Jadid (PPNurulJadid) memiliki 8.352 pengikut, dengan postingan sebanyak 496 meliputi pesan visual, pesan audi-visual. ${ }^{43}$ Masyarakat pengguna media sosial memiliki ketertarikan untuk mengikuti akun istagram dengan beragam motif. Bagi para alumni pesantren Nurul Jadid, tentunya media akun istagram menjadi bagian dari ketersambungan emosional dalam konteks almamater. Karena itu, intagram ini sangat di gemari oleh para santri alumni. Dari 496 gambar yang di posting oleh akun Instagram Pondok Pesantren Nurul Jadid antaranya adalah berbagai macam acara yang di adakan pondok pesantren Nurul Jadid, ataupun acara-acara besar yang juga mendapatkan partisipasi dari pondok pesantren. Berikut beberapa postingan yang di bagikan oleh akun Instagram Pondok Pesantren Nurul Jadid.

\footnotetext{
${ }^{41}$ Ahmad Zaini, "Dakwah Melalui Internet".

${ }^{42}$ Ahmad Zaini, "Dakwah Melalui Internet" dikutip dari Syekh Sulthan alUtami dalam makalah yang berjudul Istikhdam al-Internet fi adDa'wah (REPUBLIKA, jum'at 3 Mei 2013, hlm 4)

${ }^{43}$ Observasi oline peneliti pada 02 Januari 2019.
} 


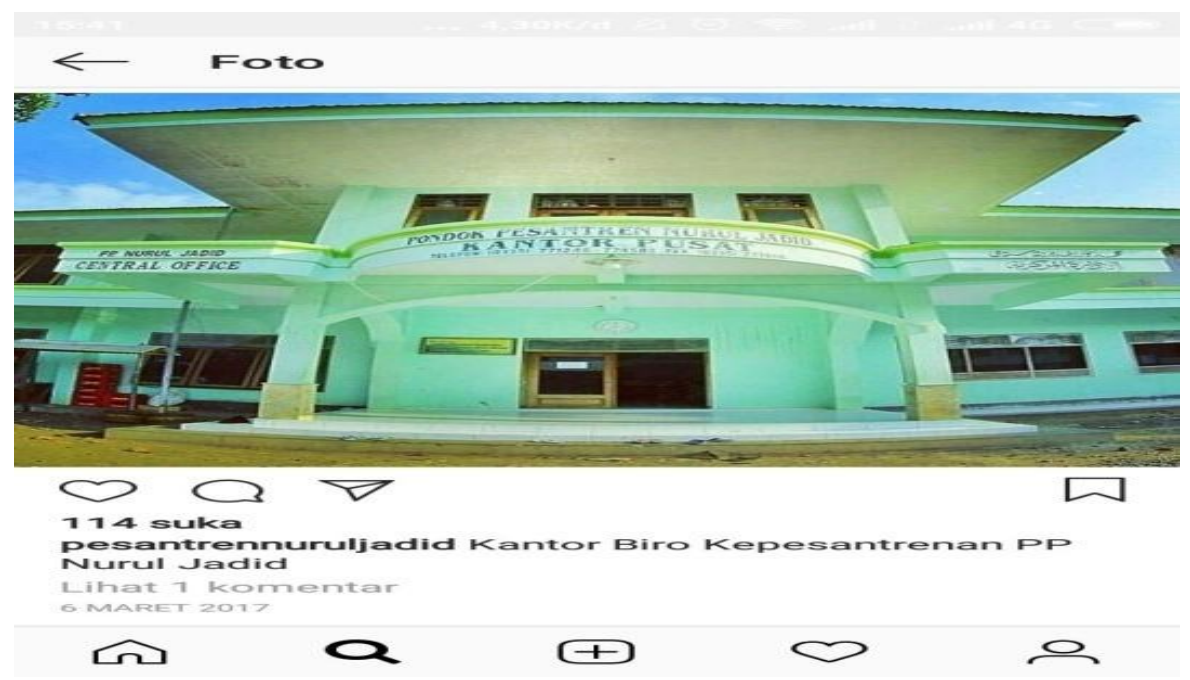

Gambar 1. Postingan perdana IG Pesantren Nurul Jadid

Pada gambar postingan tersebut pesantren Nurul Jadid diunggah sebagai pesan visual pertama untuk mengingatkan kepada para santri dan alumni serta masyarakat luas bahwa eksistensi pesantren masih terus berjalan.

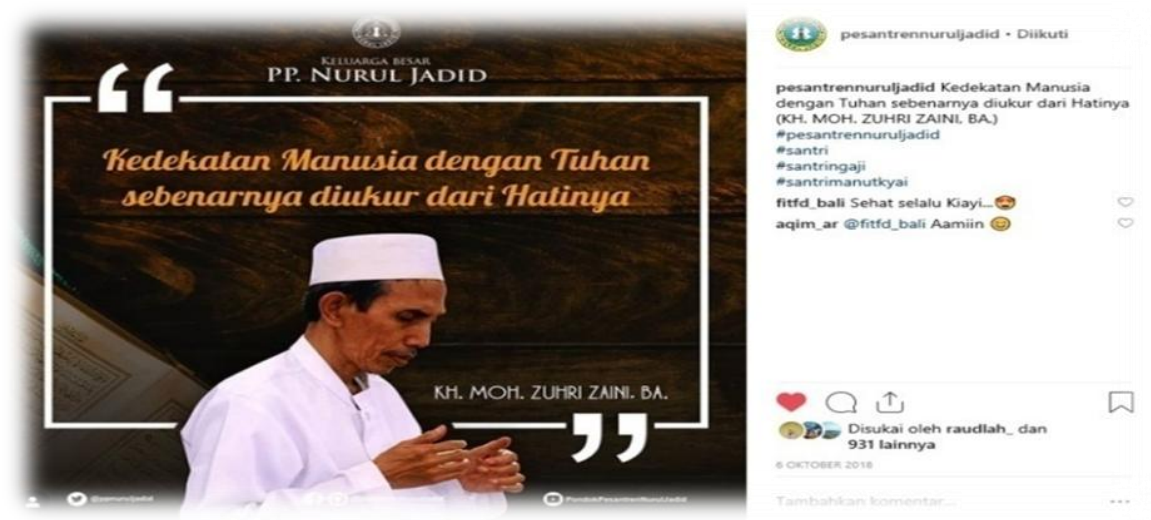

Gambar 3. postingan ini mengenai motivasi hidup. Postingan 6 Oktober 2018

Postingan pada gambar diatas menjelaskan tentang kedekatan manusia kepada Allah sang pemilik segalanya. sesuai dengan prinsip dakwah, gambar yang di posting oleh akun tersebut mengajak para follower atau pengikutnya untuk semakin mendekatkan diri kepada Allah SWT. karena kedekatan itu diukur dari hati kita. Maka, kita di anjurkan untuk membersikahkan hati terlebih dahulu. Seperti halnya memperbanyak dzikir dan selalu mengingat Allah. 

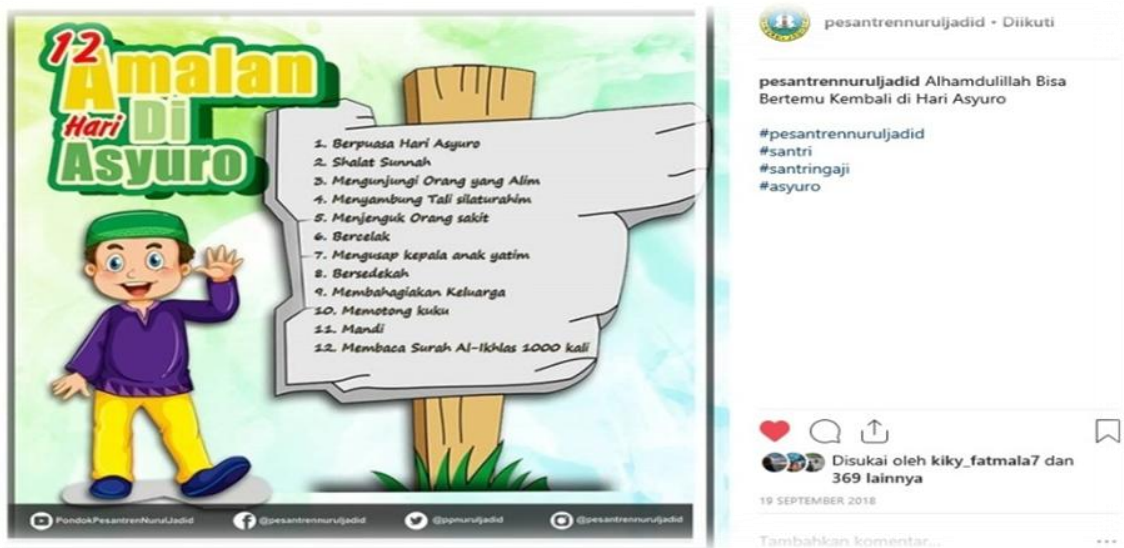

Gambar 3. Anjuran memperingati 'hari Asyuro'

Postingan ini memberitahukan dan mengingatkan kepada para pengikut untuk senantiasa melaksanakan amalan-amalan yang sudah ditetapkan. Serta mengkaji dan melakukan amalan-amalan tersebut untuk mengambil hikmah yang terkandung didalamnya. Seperti halnya sunnahsunnah yang dapat kita kerjakan dan terapkan.
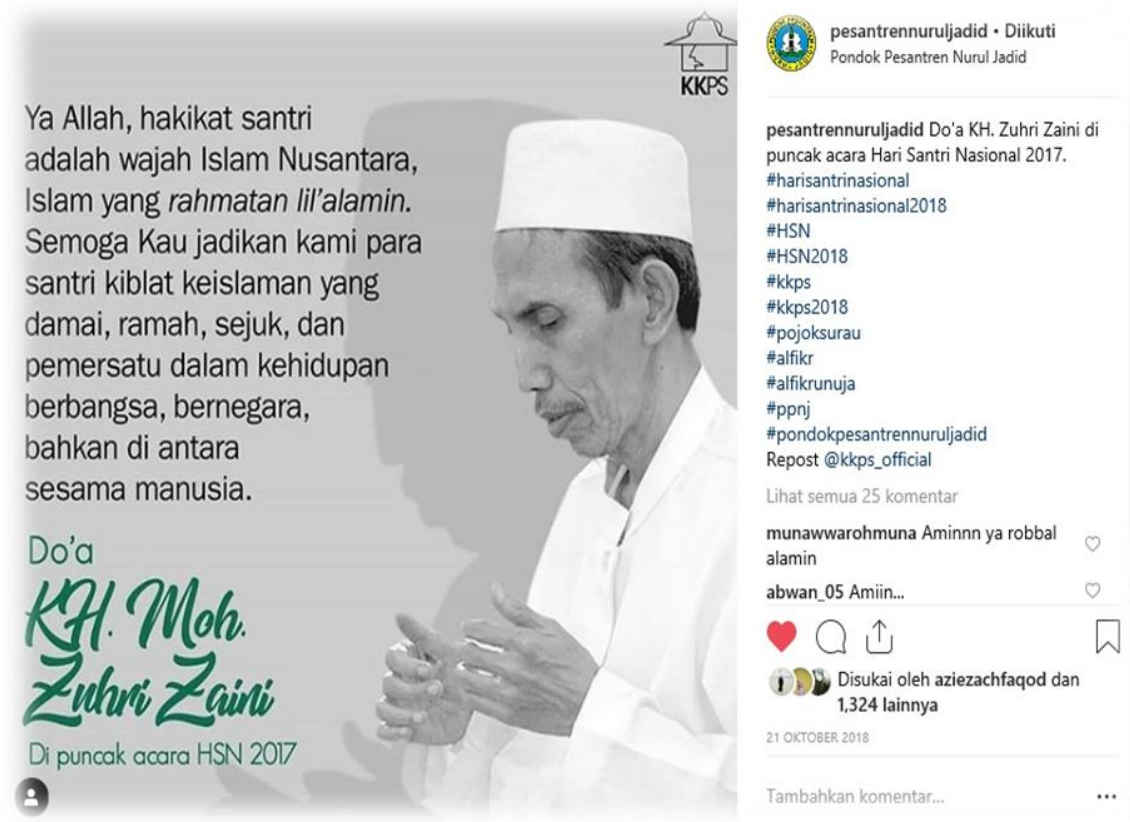

Gambar 4. Informasi kegiatan keagamaan

Postingan pada gambar 3 ini adalah salah satu postingan acara yang di adakan oleh pondok pesantren nurul jadid. Agar para pengikut atau follower mengetahui apa saja kegitan yang di adakan di pesantren ketika ada peringatan hari besar. Seperti contohnya Hari Santri Nasional dan 
acara-acara besar lainnya. Dengan begitu para pengikut atau follower akan sedikit tau bahwa Pondok Pesantren Nurul Jadid juga ikut berpartisipasi dalam acara-acara besar.

\section{Respon Pengguna Media Instagram}

Respon yang dimaksud penulis adalah motif. Motif disini adalah suatu dorongan sebagai pembangun atau penggerak untuk berbuat sesuatu. Motif ini, ada pada diri sendiri atau individu. ${ }^{44}$ Motif berasal dari bahasa latin yang berarti movere yang memiliki artian bergerak atau to move. ${ }^{45}$ Motif ini berkaitan dengan faktor lain yaitu motivasi. Motivasi disini menunjukkan keadaan dalam diri individu atau organisme yang akan mendorong perilaku kepada arah yang dituju. Maka, dengan begitu individu akan tergerak dengan sendirinya untuk melakukan sesuatu. Disini ada tiga motif pengaplikasian akun Instagram yaitu:

Motif ingin tahu; Motif ingin tahu yaitu adanya rasa keingin tahuan yang muncul dari dalam diri mahasantri untuk mengaplikasikan akun Instagram. Seiring dengan berjalannya waktu dengan semakin maraknya media sosial yang dengan di lengkapi berbagai aplikasi sehingga membuat mahasantri ikut tergiur dan memiliki rasa ketertarikan untuk mengaplikasikannya.

Motif Hiburan; Adanya keinginan untuk mencari hiburan atau kesenangan semata dalam menggunakan jejaring sosial khususnya aplikasi Instagram. Yang didalamnya terdapat berbagai hiburan baik dengan gambar atau vidio yang ada. Juga mengikuti trend dan mengikuti berbagai hal yang terkait dengan artis yang disukai, serta sebagai tempat untuk menghilangkan stres (escape the stress of the real world).

Motif Menjaga Komunikasi; Adanya keinginan untuk berkomunikasi dengan orang lain melalui aplikasi Instagram tanpa harus bertatap muka, baik dengan teman yang sudah dikenalnya maupun yang baru dikenal. Seperti halnya mendekatkan yang jauh sehingga mempermudah untuk menjalin komunikasi dan bersilaturrahmi, serta menemukan sahabat baru (companionship). Dan berinteraksi dengan orang yang memiliki hobi atau kesenangan yang sama (meet people with my interests).

\footnotetext{
${ }^{44}$ Meutia Puspita Sari, "Fenomena Pengguna Media Sosial Instagram Sebagai Komunikasi Pembelajaran Agama Islam Oleh Mahasiswa Fisip Universitas Riau", JOM FISIP, Vol. 04, No. 02, (Oktober, 2017), 01-13. https://media.neliti.com/media/publications/199560-none.pdf

${ }^{45}$ Eureka Intan Innova, "Motif Dan Kepusan Pengguna Instagram Di Komunitas Instameet Indonesia”, E-Komunikasi, Vol. 04, No. 01, (2016), 01-11.
} 
Sebelumnya peneliti memberikan pertanyaan kepada Informan mengenai tanggapan mereka terhadap pesan dakwah yang terkandung dalam akun Instagram Pondok Pesantren Nurul Jadid (PPNJ) yang sekarang lagi trend di kalangan mereka.

Menurut hasil penelitian yang didapat, alasan dari informan terhadap postingan akun Instagram Pondok Pesantren Nurul Jadid adalah sebagai berikut; motifvasi pengikut akun Instagram Pondok Pesantren Nurul Jadid.

Pengikut istagram pondok memilih akun instagram pondok pesantren nurul jadid sebagai acuan untuk mengetahui acara-acara yang akan diadakan serta acara yang sudah di laksanakan oleh Pondok Pesaantren Nurul Jadid. Seperti acara Osabar (Orentasi Santri Baru), Semarak Ramadhan, dan acara-acara lainnya yang juga mendapatkan partisipasi oleh Pondok Pesantren Nurul Jadid. Informan juga menyukai postingan-postingan lainnya sebagai ajang untuk memotivasi diri. Seperti halnya dauh atau tausiyah pengasuh yang sebagian juga di posting dan di modifikasi dengan gambar-gambar yang terkait. Serta acuan untuk mengetahui atau mengingatkan amalan-amalan serta doa-doa yang di anjurkan pada hari-hari tertentu. Seperti halnya amalan-amalan yang bisa di kerjakan pada hari Asyuro', serta amalan-amalan pada hari lainnya.

Respon pengguna Istagram terhadap pesan dakwah yang terdapat pada akun instagram Pondok Pesantren Nurul Jadid secaara umum mengatakan positif. Hal tersebut didasarkan kepada semakin bertambahnya para pengikut sebagaimana media sosial lainnya. Akun Instagram Pondok Pesantren Nurul Jadid dijadikannya sebagai wadah untuk memotivasi diri, sebagai bahan perenungan dalam melakukan aktivitas sehari-hari. Agar paradigma pribadi bisa lebih baik dari hari kehari. Sebagaimana ungkapan informan tentang pesan-pesan dakwah.

Menurut Yahya pesan yang terkandung dalam akun tersebut sangat bermanfaat dan tepat sasaran. Karena menurutnya dengan adanya pesan dakwah yang terdapat pada akun tersebut membuat mahasantri (Mahasiswa yang santri) lebih mudah untuk mengaksesnya. Dan juga sebagai media mendapatkan informasi lebih cepat seputar kegiatan-kegiatan pesantren. Sehingga dia mengungkapkan bahwa akun Instagram tersebut sebagai media dakwah yang tepat. ${ }^{46}$

Hal senada diungkapkan oleh beberapa mahasiswa lain Hanifah, mengatakan bahwa pesan dakwah tersebut cukup banyak memberikan manfaat. Karena menurutnya sudah banyak diantara mahasantri yang mengabaikan hikmah seperti halnya membaca Al-Qur'an. Sedangkan hikmah membaca Al-Qur'an itu sangat banyak, akan tetapi kebanyak

${ }^{46}$ Muhammad Yahya, Wawancara, 27 Desember 2018 
diantara para mahasantri bermales-malesan untuk sekedar membacanya. Sehingga dengan adanya pesan dakwah yang di posting oleh akun instagram Pondok Pesantren Nurul Jadid dijadikan cara untuk menggali kembali semangat untuk mencari hikmah dalam kehidupan sehari-hari. ${ }^{4}$

Begitu pula Herlina, Mengatakan bahwa adanya pesan tersebut sangatlah bermanfaat lebih-lebih bagi mahasantri yang tidak berdomisili di Pondok Pesantren. Karena pesan-pesan yang di posting tidak hanya berupa amalan-amalan yang dianjurkan, melainkan berupa acara-acara yang juga di adakan oleh Pondok Pesantren. Menurutnya dengan postingan tersebut, para mahasantri yang tidak berdomisili di pondok juga bisa ikut berpartisipasi. ${ }^{48}$

Husnan dan Ilyas juga Mengatakan bahwa dengan adanya pesan tersebut merupakan sarana positif. yaitu dengan adanya pesan tersebut bisa memberikan suasana baru, baik secara keagamaan dan keyakinan. ${ }^{49}$ Adanya pesan tersebut kita bisa mengambil hikmah yang terkandung didalamnya, juga bisa dijadikan sebagai motivasi diri. ${ }^{50}$

Pernyataan diatas menunjukkan bahwa kesemua informan dari mahasantri memberikan respon baik terhadap akun Instagram Pondok Pesantren Nurul Jadid. Indikasi pentingnya tren media masa kini sebagai bagian dari proses dakwah yang dilakukan oleh pesantren Nurul Jadid menunjukkan perkembangan dakwah yang dinamis dan fleksibel mengikuti perkembangan dan tren pengguna media sebagai objek dakwah. Hal ini, akan terus berlanjutk hingga perkembangan masyarakat modern mengikuti tren media-media baru yang kemudian akan dijadikan media dakwah yang relevan.

\section{Epilog}

Dapat disimpulkan bahwa respon mahasantri terhadap pesan dakwah pada akun Instagram Pondok Pesantren Nurul Jadid (NJ) menunjukkan hal positif. Dan telaah pesannya sangatlah menguntungkan sebagai acuan untuk menjalani kehidupan sehari-harinya, sebagai tempat untuk memotivasi diri, menggali informasi dan sebagai penghilang stress. Sehingga pesan yang terdapat pada akun Instagram Pondok Pesantren Nurul Jadid mendapatkan respon baik dari mahasantri. Mahasantri cenderung lebih mudah untuk mengetahui berbagai acara yang di adakan di Pondok Pesantren, lebih-lebih sebagai ajang untuk memotivasi dirinya.

Dengan tidak diberi batasan waktu. Maka, hal ini menunjukkan bahwa mahasantri bisa kapan saja mengaplikasikannya. Jadi dapat disimpulkan bahwa pesan dakwah dalam akun Instagram Pondok Pesantren

\footnotetext{
${ }^{47}$ Hanifah Fitri, Wawancara, 25 Desember 2019

${ }^{48}$ Ukhti Herlina, Wawancara, 27 Desember 2019

${ }^{49}$ Husnan Ariful Abadi, Wawancara, 29 Desember 2018,

${ }^{50}$ Ilyas Fahmi, Wawancara, 25 Desember 2018,
} 
Nurul Jadid (NJ) memberikan respon baik kepada Mahasantri terlebih bagi mahasantri yang tidak berdomisili di Pondok Pesantren.

\section{Daftar Pustakà}

Ajeng Jayanti Satyadewi, Hanny Hafiar, Aat Ruchiat Nugraha, 'Pemilihan Akun Media Sosial Instagram Oleh Holiday Inn Bandung', Jurnal the Messenger, 9 (2017).

Ardhi, Yogyasmara P, Wayang Kulit, Sebagai Media, Dakwah Studi, Pada Wayang, Kulit Dalang, and others, '( Studi Pada Wayang Kulit Dalang Ki Sudardi Di Desa Pringapus Semarang )', 2010

Arifin, Busnatul, 'Dakwah Cybermedia', Madzhab Hukum, 26 (2015).

Aziz, moh. Ali, Ilmu Dakwah, 2015

Farhan, 'Pesan Dakwah Felix Siauw Di Media Sosial', Jurnal Manajemen Dan Administrasi Islam, 1 (2017).

Innova, Eureka Intan, 'Motif Dan Kepuasan Pengguna Instagram Di Komunitas Instameet Indonesia', E-Komunikasi, 4 (2016).

Irwandani, siti juariah, 'Pengembangan Media Pembelajaran Berupa Komik Fisika Berbantuan Sosial Media Instagram Sebagai', Ilmiah Pendidikan Fisika Al-Biruni, 05 (2016) https://doi.org/10.24042 /jpifalbiruni.v5i1.103

M. masyhur amin, M nasikh ridwan, KH Zaini Mun'im (Pengabdian Dan Karya Tulis), 1996

Munir, M, Metode Dakwah, 2003

Sari, meutia puspita, 'Fenomena Pengguna Media Sosial Instagram Sebagai Komunikasi Pembelajaran Agama Islam Oleh Mahasiswa Fisip Universitas Riau', JOM FISIP, 4 (2017).

Siti Juariah Irwandani, "Pengembangan Media Pembelajaran Berupa Komik Fisika Berbantuan Sosial Media Instagram Sebagai Alternatif Pembelajaran", Ilmiah Pendidikan Fisika Al-Biruni, 05.April (2016)

ST.Nasriah, 'Surat Kabar Sebagai Media Dakwah', Dakwah Tabligh, 13 (2012).

Wicaksono, M. Arifin, 'Pengaruh Media Sosial Instagram 'wisatadakwahokura Terhadap Minat Berkunjung FOLLOWERS', JOM FISIP, 4 (2017).

Zaini, A, 'DAKWAH MELALUI INTERNET', Komunikasi Penyiaran Islam, 1 (2013). 